\title{
PENERAPAN STANDAR PROFESIONAL AUDIT INTERNAL DAN KUALITAS AUDIT: SEBUAH TINJAUAN LITERATUR
}

\author{
MELINDA CAHYANING RATRI \\ YUSTRIDA BERNAWATI \\ Departemen Akuntansi, Fakultas Ekonomi dan Bisnis, Universitas Airlangga, Jl. Airlangga No.4 - 6, Surabaya, \\ Jawa Timur 60115, Indonesia \\ melinda.cahyaning.ratri-2018@feb.unair.ac.id
}

\begin{abstract}
The application of internal audit attribute and performance standards is a features that is important because it can demonstrate internal audit quality. The purpose of this paper is provide a review of literature related to the compliance in the application of the International Professional Standards for Internal Audit Practices issued by the Institute of Internal Auditors (IIA). This article describes developing internal audit practices, which are focused on compliance and commitment to internal audit professional standards. The compliance of internal auditor can provide benefits to the company, not only to achieve company goals but also can reflect a good reputation and improve the quality of internal audits. The explanation in this article is expected to enrich the literature related to internal audit standards and can help management in choosing the internal auditor.
\end{abstract}

Keywords: Internal audit, internal audit standard, audit quality

Abstrak: Penerapan standar atribut dan standar kinerja audit internal adalah salah satu fitur paling penting yang dapat menunjukkan kualitas audit internal. Artikel ini bertujuan untuk memberikan tinjauan literatur terkait dengan pentingnya kepatuhan dalam penerapan Standar Profesional Internasional untuk Praktik Audit Internal yang dikeluarkan oleh Institute of Internal Auditor (IIA). Artikel ini menjelaskan perkembangan praktik audit internal, yang berfokus pada kepatuhan dan komitmen terhadap standar profesional audit internal. Perusahaan dapat memperoleh manfaat dari kepatuhan auditor internal, selain dapat membantu perusahaan mencapai tujuannya juga mencerminkan reputasi perusahaan yang baik dan dapat meningkatkan kualitas audit internal. Penjelasan dalam artikel ini diharapkan dapat memperkaya literatur yang terkait dengan standar audit internal dan dapat membantu manajemen dalam memilih auditor internal.

Kata kunci: Audit internal, standar audit internal, kualitas audit

\section{PENDAHULUAN}

Baru-baru ini investor dan regulator semakin menaruh perhatian terkait dengan kebangkrutan, yang dipicu oleh adanya skandal kebangkrutan perusahaan, seperti Enron, Worldcom, dan Satyam (2009) atau biasa disebut "Enron India". Skandal ini mengungkapkan situasi di mana perusahaan memiliki peluang untuk terlibat dalam strategi akuntansi yang tidak etis untuk menghilangkan informasi yang relevan tentang data keuangan perusahaan (Cohen et al. 2012). Untuk meringankan kekhawatiran ini dan memberi investor kepercayaan atas investasinya otoritas telah 
memperkenalkan inisiatif untuk memperbaiki struktur kontrol internal perusahaan, yaitu melalui fungsi audit internal yang efektif. Audit internal adalah suatu mekanisme dalam sistem pengendalian internal yang dapat memberikan manfaat pada efektivitas operasi perusahaan (Salehi et al. 2013). Menurut Muceku dan Korsita (2010), audit internal dapat meningkatkan nilai dan operasi organisasi melalui konsultasi yang independen dan objektif. Manajemen dapat menggunakan audit internal sebagai sarana untuk memastikan dan memverifikasi komitmen unit administratif dengan kebijakan keuangan, administratif, dan legislatif, sistem keuangan dan administrasi, dan kebijakan umum yang diterapkan perusahaan (Rahahleh 2010). Kegiatan penilaian secara menyeluruh dan berkala atas operasi perusahaan menghasilkan audit internal yang efektif sehingga memperkecil kemungkinan terjadinya kecurangan yang mengakibatkan kegagalan perusahaan.

Dalam menjalankan tugasnya, praktik, prosedur umum, dan etika auditor internal dalam bekerja perlu diatur menggunakan serangkaian aturan dan standar (Robert 2016). Standar yang dijadikan pedoman wajib oleh auditor internal di seluruh dunia adalah Standar Profesional Internasional untuk Praktik Audit Internal atau biasa disebut dengan International Professional Practices Framework (IPPF) (IIA 2017). Kerangka kerja konseptual IPPF merupakan yang mengatur praktik auditor internal secara resmi dan diterbitkan oleh Institut Auditor Internal (IIA). Auditor internal yang baik harus mematuhi dan berkontribusi pada pengembangan standar profesional internal audit (Bank for International Settlements 2012). IPPF telah melalui beberapa kali revisi mulai dari pertama kali dikeluarkan pada tahun 1978 hingga amandemen yang terbaru pada tahun 2017. Pada mulanya standar tersebut hanya mengatur mencakup tanggung jawab auditor internal dalam berbagai aspek audit internal dalam organisasi, seperti independen, kecakapan profesional, melakukan pekerjaan secara akurat dan efisien dan manajemen departemen audit internal (Institute of Internal Auditors 1995). Dalam IPPF terbaru dijelasakan bahwa fungsi audit internal tidak hanya melakukan penilaian tetapi juga mampu memberikan pandangan kedepan bagi organisasi (IIA 2017). Auditor internal harus dapat berkontribusi pada tata kelola dan manajemen risiko dengan cara menilai kecukupan pengendalian yang dibentuk untuk memitigasi risiko tersebut ke level yang dapat diterima (IIA 2017). Perubahan standar ini mencerminkan bahwa praktik profesi audit internal terus berubah (Idiab et al. 2012).

Berdasarkan Standar Profesi Audit Internal (1210.2) disebutkan bahwa dalam mendeteksi indikasi adanya kecurangan, pengetahuan yang dimiliki auditor internal harus cukup dan memadai. Pernyataan Standar Internal Audit (SIAS No.3) juga menyebutkan bahwa dalam melaksanakan audit, auditor internal diwajibkan untuk waspada terhadap segala bentuk kecurangan, penyimpangan, dan adanya konflik kepentingan. Adanya berbagai standar dan aturan yang mengikat bagi auditor internal, diharapkan fungsi audit internal mendorong perusahaan beroperasi secara efektif dan efisien. Efektivitas fungsi audit internal dalam suatu organisasi dapat memperkuat sistem pengendalian internal. Lebih lanjut, sistem pengendalian internal yang tangguh dapat mendukung perusahaan untuk memastikan bahwa tujuannya akan terpenuhi, dimana perusahaan akan dapat mencapai target profitabilitas jangka panjang dan tetap mempertahankan pelaporan keuangan yang andal (Gamage et al. 2014). Perusahaan dipastikan akan mematuhi prosedur, aturan internal, rencana, dan undang-undang serta peraturan yang berlaku, dan juga dapat mengurangi risiko rusaknya reputasi atau kerugian yang tidak 
terduga, jika sistem pengendalian internal berjalan dengan baik (Gamage et al. 2014).

Kepatuhan auditor internal terhadap standar IIA telah diperiksa oleh banyak penelitian di berbagai negara (Abdolmohammadi 2009, Abdolmohammadi dan Sarens 2011, Burnaby dan Hass 2011, Steyn et al. 2013). Auditor internal yang melaksanakan tanggung jawabnya dengan baik dan mematuhi standar profesional audit internal dapat meningkatkan kualitas audit. Menurut Butcher et al. (2013), kualitas audit merupakan kemampuan dalam mendeteksi dan melaporkan penyimpangan dan/atau pelanggaran. Daniels dan Booker (2011) menekankan bahwa independensi dan obyektivitas merupakan kontributor utama untuk kualitas audit. Tingkat kualitas dalam menemukan dan melaporkan penyimpangan dan pelanggaran tergantung pada kemahiran, kemandirian dan obyektivitas (Al Matarneh, 2011). Selain dapat meningkatkan kualitas audit, diharapkan fungsi audit internal juga mampu meningkatkan operasi dengan efektif dan efisien, menciptakan pelaporan keuangan yang handal serta adanya pengamanan aset (Hayes et al. 2005).

Kepatuhan auditor internal terhadap standar yang dikeluarkan oleh IIA dapat memberikan manfat bagi perusahaan, tidak hanya untuk mencapai tujuan perusahaan melainkan dapat mencerminkan reputasi yang baik di mata investor dan stakeholders lainnya.

Dengan demikian, mengingat pentingnya peran audit internal dalam tata kelola perusahaan dan sistem pengendalian internal perusahaan, maka artikel ini ingin mengulas lebih dalam bagaimana penerapan standar IIA oleh auditor internal dapat memberikan kualitas audit yang lebih baik. Artikel ini bertujuan untuk memberikan tinjauan literatur terkait dengan pentingnya kepatuhan dalam penerapan Standar Profesional Praktik Audit Internal yang diterbitkan oleh Institute of Internal Auditor (IIA). Diharapkan artikel ini dapat memperkaya literatur yang terkait dengan standar audit internal dan manajemen perusahaan dapat terbatu ketika dihadapkan pilihan dalam memilih auditor internal.

\section{Standar Audit Internal}

Audit internal merupakan suatu upaya konsultasi yang objektif dan independen yang dibuat sedemikian rupa untuk memberikan nilai tambah dalan aktivitas dan operasi organisasi (Muceku dan Korsita 2010). Konsep dan metodologi yang mendasari audit internal kontemporer dimulai sekitar tahun 1941 yang dipelopori oleh Institute of Internal Auditor (IIA). Institut Auditor Internal (IIA) adalah asosiasi profesional internasional yang didirikan di Florida, Amerika Serikat sebagai suatu lembaga yang memiliki otoritas, pemimpin yang diakui, penasihat utama, dan pendidik utama dalam profesi audit internal global (IIA 2017). IIA berkontribusi untuk mengklarifikasi dan mengembangkan konsep, metodologi dan mekanisme audit internal. IIA pertama kali mengeluarkan standar audit internal pada tahun 1978. Standar tersebut adalah produk dari aturan kerja yang ketat dan terpadu untuk praktik audit internal di seluruh dunia (Abdolmohammadi 2009).

Dalam praktiknya, standar IIA telah mengalami beberapa kali perubahan yang mencerminkan bahwa praktik profesi audit internal adalah dinamis dan terus berubah (Idiab et al. 2012). Pada tahun 1999, untuk memenuhi kebutuhan organisasi yang semakin berkembang, ruang lingkup kerja intenal audit meningkat mencakup beberapa kegiatan tambahan. Hal ini menyebabkan perubahan paradigma dalam kegiatan auditor internal, dari yang bertanggung jawab pada layanan penjaminan yang berkaitan dengan pengendalian internal, menjadi memasukkan penjaminan di bidang tata kelola dan manajemen risiko (Cooper et al. 2009). 
Perluasan paradigma tersebut memungkinkan auditor internal untuk memberikan layanan konsultasi kepada manajemen organisasi, dewan direktur dan komite audit. Saat ini, standar diperbarui untuk mencakup tiga bidang yaitu manajemen risiko, pengendalian internal, dan tata kelola (corporate governance) serta memastikan keterlibatan auditor internal untuk penjaminan dan konsultasi (IIA 2017).

Standar audit internal IIA atau yang biasa disebut dengan IPPF dianggap sebagai pedoman dan bukti yang mengatur praktik audit internal di dunia di bawah kerangka praktik standar profesional yang komprehensif, kode etik dan pedoman untuk menjelaskan bagaimana menerapkan dan melaksanakan praktek yang secara ketat dipatuhi (Rahahleh 2010). IPPF dapat membantu dalam meningkatkan efisiensi dan efektivitas organisasi, dengan cara memberikan pedoman bagi komite audit dan manajemen untuk mengukur kinerja auditor internal. Selain itu juga menjadi pedoman bagi para auditor internal untuk mengukur diri mereka sendiri sehingga mereka dapat mengetahui pencapaian dan kendala dalam aktivitas audit internal yang dilakukan. Secara garis besar, standar IIA dirancang dengan tujuan untuk (Robert 2016, IIA 2017) 1. Mendeskripsikan prinsip utama atau dasar untuk praktik audit internal

2. Memberikan framework untuk melakukan dan mempromosikan berbagai kegiatan audit yang bernilai tambah

3. Sebagai dasar untuk mengukur kinerja audit internal

4. Membantu perkembangan aktivitas operasi perusahaan atau organisasi.

Struktur standar praktik profesional audit internal dibagi menjadi atribut dan kinerja. Sifat dan ciri-ciri organisasi dan auditor yang melakukan audit internal dan diterapkan pada semua layanan audit internal dibahas dalam standar atribut. Sedangkan sifat kegiatan audit internal dan kriteria kualitas yang dapat mengukur kinerja pelayanannya dibahas dalam standar kinerja. Kedua standar ini berlaku untuk semua bidang layanan internal audit serta auditor internal (IIA 2017).

Selain standar profesional audit internal, profesi audit internal juga perlu memahami kode etik profesi. Kode etik IIA dibentuk dengan tujuan untuk mempromosikan budaya etis untuk profesi audit internal (Robert 2016). Dengan menerapkan kode etik dalam lingkungan organisasi, maka akan mendukung kepercayaan para pengguna layanan audit internal terkait jaminan obyektif yang diberikan tentang pengendalian internal, manajemen risiko, dan tata kelola. Kode etik ini didasarkan pada prinsip integritas, objektivitas, kerahasiaan, dan kompetensi auditor internal (Robert 2016). Prinsip-prinsip tersebut merupakan norma perilaku yang baik yang harus diterapkan auditor internal dan dimaksudkan untuk memandu perilaku etis mereka. Kode etik IIA ini berlaku untuk individu dan entitas yang menyediakan layanan audit internal.

\section{METODA}

Penelitian ini merupakan penelitian studi literatur yang membahas artikel-artikel penelitian terdahulu mengenai kepatuhan dalam penerapan Standar Profesional Internasional untuk Praktik Audit Internal. Artikel ini lebih berfokus untuk membahas hasil dari penelitianpenelitian sebelumnya terkait dengan praktik auditor internal dalam menerapkan Standar Profesional Internasional untuk Praktik Audit Internal untuk mewujudkan kualitas audit yang lebih baik.

\section{HASIL}

\section{Praktik Auditor Internal di Seluruh Dunia}

Kegiatan audit internal didefinisikan sebagai kegiatan evaluasi independen untuk 
membantu manajemen perusahaan dalam mengelola bisnis mereka secara efektif, efisien, dan ekonomis (Jumaa, 2006). Selain itu, audit internal juga didefinisikan sebagai kegiatan penjaminan dan konsultasi independen yang dibentuk untuk meningkatkan dan menambah nilai operasi suatu organisasi. Tujuan perusahaan dapat dicapai melalui peran auditor internal melalui pendekatan yang terstuktur dan ketat untuk mengevaluasi efisiensi dalam manajemen risiko, pemantauan, dan pengendalian (IIA 2017, Rahahleh 2010). Dalam menjalankan tugasnya, auditor internal bertanggungjawab untuk menentukan apakah pengendalian perusahaan sudah tepat, ditandai dengan mempertanyakan apakah informasi manajemen andal dan mencerminkan kondisi sebenarnya dan apakah kegiatan operasional perusahaan telah berjalan dengan baik.

Praktik auditor internal telah mengalami perubahan dan perbaikan. Pada mulanya audit internal bertujuan untuk memberikan jaminan dan saran bagi organisasi. Namun, dalam perkembangannya audit internal yang berhasil perlu memberikan jaminan proaktif dan membantu organisasi dalam mengimbangi dan menghadapi risiko yang muncul (Delloite 2018). Peran dan tanggung jawab audit internal terus bervariasi berdasarkan pada banyak faktor termasuk jenis organisasi, pandangan mereka tentang audit internal, pemahaman mereka tentang Kerangka Kerja IPPF dan budaya keseluruhan organisasi (Fountain, 2016). Selain itu, dalam banyak kasus peran audit internal telah ditetapkan oleh manajemen sebelumnya dan ditugaskan untuk meninjau masalah terkait kepatuhan dan pengendalian (Fountain 2016). Auditor internal bertanggungjawab dalam penyusunan sistem pengendalian internal yang komprehensif sebagai instrumen manajemen risiko, termasuk penerapan kontrol internal yang sesuai dalam sistem bisnis dan kepedulian konstan bahwa fungsinya secara signifikan dapat berkontribusi pada realisasi strategi risiko yang dipilih oleh manajemen (Moeller 2009). Kegiatan audit internal terus ditekankan pada proses penciptaan nilai tambah, terutama dengan menghasilkan informasi yang diperlukan untuk identifikasi, pemahaman, dan penilaian risiko.

\section{Kualitas Audit dari Auditor Internal}

Kualitas audit didefinisikan sebagai kemampuan untuk menemukan dan melaporkan penyimpangan dan/atau pelanggaran (Butcher et al. 2013, Daniels dan Booker 2011). Berdasarkan penelitian sebelumnya, terdapat dua dimensi yang berperan sebagai kontributor utama terhadap kualitas audit, yaitu independensi dan obyektivitas internal audit. Tingkat kualitas dalam menemukan dan melaporkan penyimpangan dan pelanggaran tergantung pada kemahiran, kemandirian dan obyektivitas (Al Matarneh 2011).

Kualitas audit internal yang tinggi mencerminkan harapan dari fungsi audit internal yang tepat, mencakup pengendalian efektivitas dan efisiensi operasi, tingkat keberhasilan kepatuhan dalam peraturan dan prosedur internal, keandalan pelaporan keuangan, dan pengamanan aset (Hayes et al. 2005). Dengan demikian dapat disimpulkan bahwa kepuasan dari harapan atas fungsi audit internal yang tepat menunjukkan tingkat kualitas kegiatan audit internal. Oussii dan Boulila (2018) menjelaskan bahwa kualitas audit internal yang tinggi dapat diperoleh melalui kompetensi yang dimiliki oleh auditor internal, tingkat jaminan dan proses tindak lanjut yang diberikan, serta fungsi komite audit dalam mengevaluasi dan meninjau hasil audit internal. Kualitas yang baik dari audit internal pada akhirnya dapat meningkatkan kualitas dari pelaporan keuangan, karena kualitas internal audit adalah elemen penting dari pengendalian internal yang efektif yang menjadi dasar untuk kualitas pelaporan keuangan (Ashbaugh-Skaife et al. 2008, Doyle et al. 2007).

\section{Kepatuhan terhadap Standar IIA dan Kualitas Audit}

Kualitas kinerja auditor internal dan hasil auditnya dapat dilihat dari upaya yang dilakukan untuk memenuhi ketentuan dalam standar profesi internal auditor (IIA 2017). IIA menegaskan bahwa 
Standar IIA adalah sumber otoritatif untuk praktik audit internal oleh individu dan organisasi di seluruh dunia. Standar harus dipenuhi oleh semua orang yang melakukan audit internal. Kualitas profesional auditor internal serta bagaimana auditor mempertimbangkan dan mengambil keputusan terkait pemeriksaan dan pelaporan sangat ditekankan dan diatur dalam standar. Auditor internal yang mematuhi standar dapat memberikan kualitas audit yang baik, yang selanjutnya dapat membantu perusahaan untuk mencapai tujuan dan meningkatkan efektivitasnya. Dalam menjalankan tugasnya, auditor internal selain dituntut untuk mematuhi standar yang berlaku juga perlu memiliki Common Body of Knowledge (CBOK) yang memadai. CBOK digunakan oleh auditor untuk memperluas pemahaman tentang bagaimana audit internal dipraktikkan di seluruh dunia (Leung dan Cooper 2009).

Beberapa penelitian sebelumnya telah banyak dilakukan untuk melihat bagaimana kepatuhan terhadap Standar Profesional Audit Internal yang dikeluarkan oleh Institut Auditor Internal (IIA). Steyn et al. (2013) menganalisis hasil survei CBOK 2010 untuk benua Afrika. Hasil penelitiannya menunjukkan bahwa lebih dari setengah responden mengkonfirmasi bahwa mereka sepenuhnya mematuhi standar. Nilai terendah yang muncul pada standar atribut adalah "jaminan kualitas dan peningkatan program" dan sedangkan pada standar kinerja adalah "penerimaan risiko manajemen". Karcioglu dan Yanik (2010) memeriksa tingkat kepatuhan standar audit internal di 500 perusahaan manufaktur terbesar di Turki. Hasilnya menemukan bahwa tingkat kepatuhan tinggi meskipun ada perbedaan yang signifikan antara perusahaan yang dianalisis karena terdapat beberapa data demografis seperti jumlah karyawan dan sektor. Al Matarneh (2011) meneliti kualitas audit internal di bank-bank Yordania. Penelitian dilakukan dengan menggunakan kuesioner dan hasilnya menunjukkan bahwa auditor internal di bank-bank Yordania menganggap kompetensi, obyektivitas, dan kinerja auditor internal sebagai faktor penting yang mempengaruhi kualitas audit internal.

Faudziah et al. (2005) juga melakukan penelitian pada fungsi audit internal perusahaan publik di Malaysia sesuai dengan Standar Praktik Profesional Auditor Internal. Hasilnya menunjukkan bahwa manajemen departemen audit internal memiliki kemahiran profesional dan obyektivitas yang secara signifikan dapat mempengaruhi aspek pemantauan sistem pengendalian internal. Gill et al. (2012) meneliti 47 fungsi audit internal dan kualitas pelaporan keuangan dengan mengumpulkan data dengan menggunakan kuesioner di Spanyol. Hasilnya menunjukkan bahwa audit internal yang terlibat secara keseluruhan dalam meninjau laporan keuangan akan mengarah pada kualitas pelaporan keuangan yang lebih baik.

Berdasarkan hasil penelitian sebelumnya terlihat bahwa auditor internal memiliki pandangan positif terhadap standar yang berlaku. Auditor internal memiliki peran yang utama dalam menciptakan tata kelola perusahaan yang baik yang dilakukan melalui tugasnya dalam proses pengendalian internal, mitigasi risiko dan kepatuhan terhadap standar. Lebih lanjut, kepatuhan terhadap standar dapat membuat auditor internal dapat menjadi inovatif dan lebih aktif terlibat dalam masalah konsultasi dan penasehat internal.

\section{PENUTUP}

Audit internal adalah kegiatan independen yang bertujuan untuk melaksanakan layanan jaminan dan berbagai kegiatan konsultasi independen untuk menawarkan penambahan nilai bagi perusahaan dan meningkatkan efektifitas operasinya. Dalam pelaksanaannya, terdapat standar yang mengatur praktik dan etika dari auditor internal, yaitu Standar Praktik Audit Internal oleh IIA. Kepatuhan auditor internal terhadap standar dapat memberikan manfat bagi perusahaan, tidak hanya untuk mencapai tujuan perusahaan melainkan dapat mencerminkan reputasi yang baik di mata investor dan 
stakeholders lainnya. Selain itu, auditor internal yang melaksanakan tanggung jawabnya dengan baik dan mematuhi standar yang berlaku dapat meningkatkan kualitas audit internalnya. Ini dikarenakan kemandirian dan obyektivitas dari auditor internal menjadi komponen penting dalam menentukan tingkat kualitas dalam menemukan dan melaporkan penyimpangan dan pelanggaran yang terjadi.

Artikel ini memberikan implikasi bagi manajemen perusahaan bahwa keberadaan auditor internal yang kompeten, independen, dan objektif dapat memberikan manfaat bagi perusahaan, salah satunya adalah meningkatkan kualitas audit. Dengan demikian, untuk memperoleh hasil audit yang berkualitas, manajemen perusahaan dan organisasi profesi dapat mendorong dan memastikan auditor internal untuk patuh dan mengaplikasikan standar dan kode etik profesional internal audit. Berdasarkan uraian diatas peneliti merekomendasikan beberapa hal untuk para praktisi audit internal yaitu:
1. Auditor internal harus tetap independen dari aktivitas-aktivitas di mana profesionalisme diperlukan.

2. Auditor harus memastikan bahwa departemen audit internal memiliki ketersediaan pelatihan teknis, pengetahuan, keterampilan, dan aset untuk melaksanakan tanggungjawab dan pengawasan yang memadai.

3. Auditor internal harus mematuhi standar profesional audit internal serta memiliki keterampilan dan kemampuan untuk berkomunikasi secara efektif.

4. Auditor internal harus mempertahankan kemampuan teknisnya melalui pendidikan berkelanjutan dan berbagai kursus pelatihan, guna untuk mendapatkan pengetahuan yang diperlukan dalam melakukan audit yang terus berkembang.

5. Auditor internal harus menjunjung tinggi standar profesional audit internal, mempertahankan kehormatan dan kejujuran, guna memastikan bahwa audit dilakukan dengan cara yang tepat.

\section{REFERENCES:}

Abdolmohammadi, M. J. 2009. Factors Associated with the Use of and Compliance with the IIA Standards: A Study of Anglo-culture CAEs. International Journal of Auditing, 13(1), pp.27-42. https://doi.org/10.1111/j.10991123.2008.00393.x

Abdolmohammadi, M. J., dan G. Sarens. 2011. An investigation of the association between cultural dimensions and variations in perceived use of and compliance with internal auditing standards in 19 countries. The International Journal of Accounting, 46(4), pp.365-389. https://doi.org/10.1016/j.intacc.2011.09.004

Al-Thuneibat, A. A., A. S. Al-Rehaily, dan Y. A. Basodan. 2015. The impact of internal control requirements on profitability of Saudi shareholding companies. International Journal of Commerce and Management, 25(2), pp.196-217. https://doi.org/10.1108/ijcoma-04-2013-0033

Al Matarneh, G. F. 2011. Factors determining the internal audit quality in banks: Empirical Evidence from Jordan. International Research Journal of Finance and Economics, 73, pp.99-108. https://doi.org/10.5539/ibr.v5n9p128

Ashbaugh-Skaife, H., D. W. Collins, W. R. Kinney, dan R. LaFond. 2008. The effect of SOX internal control deficiencies and their remediation on accrual quality. The Accounting Review, Vol. 83 No. 1, pp. 217-250.

Burnaby, P. A., dan S. Hass. 2011. Internal auditing in the Americas. Managerial auditing journal, 26(8), pp.734756. https://doi.org/10.2308/accr.2008.83.1.217

Butcher, K., G. Harrison, dan P. Ross. 2013. Perceptions of audit service quality and auditor retention. International Journal of Auditing, 17(1), pp.54-74. https://doi.org/10.1111/j.1099-1123.2012.00457.x

Bank for International Settlements. 2012. Principles for enhancing corporate governance. Basel Committee on Banking Supervision. 
Cohen, J., Y. Ding, C. Lesage, dan H. Stolowy. 2012. Corporate fraud and managers' behavior: Evidence from the press. In Entrepreneurship, governance and ethics (pp. 271-315). Springer, Dordrecht. https://doi.org/10.1007/978-94-007-2926-1_8

Cooper, B. J., P. Leung, S. Dellaportas, M. Marais, P. A. Burnaby, S. Hass, dan H. Fourie. 2009. Usage of internal auditing standards and internal auditing activities in South Africa and all respondents. Managerial Auditing Journal. https://doi.org/10.1108/02686900910994818

Daniels, B. W., dan Q. Booker. 2011. The effects of audit firm rotation on perceived auditor independence and audit quality. Research in Accounting Regulation, 23(1), pp.78-82. https://doi.org/10.1016/j.racreg.2011.03.008

Delloite. 2018. Internal Audit 3.0 The future of Internal Audit is now.

Doyle, J., W. Ge, dan S. McVay. 2007. Determinants of weaknesses in internal control over financial reporting. Journal of Accounting and Economics, Vol. 44 Nos 1/2, pp. 193-223. https://doi.org/10.1016/j.jacceco.2006.10.003

Faudziah, H. F., H. Hasnah, dan J. Muhamad. 2005. Internal Auditing Practices and Internal Control System. Managerial Auditing Journal, 20(8), 844 - 866. https://doi.org/10.1108/02686900510619683

Fountain, L. 2016. Leading the Internal Audit Function. EDPACS, 53(2), 14-17. doi:10.1080/07366981.2016.1140515

Gamage, C. T., K. L. Lock, dan A. A. J. Fernando. 2014. A proposed research framework: Effectiveness of internal control system in state commercial banks in Sri Lanka. International Journal of scientific research and innovative technology, 1(5), 25-44.

Gill, G. E., M. S. Hernandez, dan D. G. de Lema. 2012. Internal audit and financial reporting in the Spanish banking industry. Managerial Auditing Journal, 27(8), 728-753. https://doi.org/10.1108/02686901211257028

Hayes, R., R. Dassen, A. Schilder, dan P. Wallage. 2005. Principles of Auditing an Introduction to International Standardson Auditing. (Essex, Ed.). UK: Pearson Education.

Hussaini, U., dan U. Muhammed. 2018. The effect of internal control on performance of commercial banks in Nigeria. International Journal of Management Research \& Review, 8(6), 13-32.

Idiab, A. I. M., M. S. bin Haron, dan S. B. H. Ahmad. 2012. Standards of professional practice and professional conduct of internal audit. Advances in Natural and Applied Sciences, 6(6), pp.930-936.

Institute of Internal Auditors. 1995. Codification of Standards for the Professional Practice of Internal Auditing. Altamonte Spring Florida, UA, PP 9-12.

Institute of Internal Auditors. 2017. International standards for the professional practice of internal auditing, 1-25.

Jumaa, A. H. 2006. Senior Management Awareness of the Evolution of Knowledge in the Profession of Internal Auditing and Its Impact On Internal Auditors Role in Jordanian Business Organizations. Arab Journal of Administrative Sciences, 1.

Karcioglu, R., dan R. Yanik. 2010. Internal audit international standards and an application in the first industrial corporations 500 big Turkey. Journal of Economics and Administrative Sciences, 24(4), 229-241.

Leung, P., dan B. J. Cooper. 2009. Internal audit - an Asia-Pacific profile and the level of compliance with Internal Auditing Standards, 24(9), 861-882. https://doi.org/10.1108/02686900910994809

Muceku, H., dan B. Korsita. 2010. The Role of Internal Auditing Activity to Improve Management and Increase the Value of Public Entities. Journal of Studies in Economics and Society, II(1), 181-195.

Moeller, R. 2009. Brink's modern internal auditing, a common body of knowledge (Seven ed.). Hoboken, NJ: Wiley.

Oussii, A. A., dan N. Boulila. 2018. The impact of internal audit function characteristics on internal control quality. Managerial Auditing Journal, 33(5), 450-469. https://doi.org/10.1108/maj-06-2017-1579

Rahahleh, M. Y. 2010. Regulating the Profession of Internal Auditing in Jordan. European Journal of Economics, Finance and Administrative Sciences, 20(20).

Robert, R. M. 2016. Brink's Modern Internal Auditing: A Common Body of Knowledge (8 Edition). John Wiley \& Sons.

Salehi, M., A. Arianpoor, dan F. Salehi. 2013. Investigating the Effect of Internal Audit on the Performance of Private Banks' System. Journal of Accounting, Business \& Management, 20(1). 
Steyn, B., K. Barac, K. N. Motubatse, dan K. Plant. 2013. Views on the applicability of the internal audit standards and competencies for internal auditors: An African perspective. Southern African Journal of Accountability and Auditing Research, 15, 3-16. 
